KERTHA PATRIKA

Volume 38, Nomor 1, Januari-April 2016

\title{
IMPLEMENTASI PENGATURAN REHABILITASI PENYALAH GUNA NARKOTIKA OLEH BADAN NARKOTIKA NASIONAL KOTA DENPASAR
}

Oleh :

\author{
Sagung Putri M. E. Purwani, ${ }^{1}$ Anak Agung Ngurah Yusa Darmadi, ${ }^{2}$ I Made Walesa Putra ${ }^{3}$ \\ Fakultas Hukum Universitas Udayana
}

\begin{abstract}
Abstrak
Artikel ini membahas kewenangan Badan Narkotika Nasional Kota (BNNK) Denpasar dalam penerapan rehabilitasi bagi penyalahgunaan narkotikaserta menganalisis implementasi aturan mengenai rehabilitasi terhadap penyalah guna narkotika oleh BNNK Denpasar. Tulisan ini merupakan penelitian hukum yang mengkombinasikan karakteristik penelitian hukum normatif dengan menggunakan pendekatan peraturan perundang-undangan dan adopsi terhadap model socio-legal research berkaitan dengan pelaksanaan penelitian lapangan ke BNNK Denpasar dalam rangka menelusuri data, memperoleh informasi dan melakukan wawancara (interview). Artikel ini menyimpulkan bahwa BNNK memiliki kewenangan dalam penerapan rehabilitasi bagi penyalahgunaan Narkotika sebagaimana diatur di dalam Peraturan Presiden Republik Indonesia Nomor 23 Tahun 2010 tentang Badan Narkotika Nasional dan sejumlah Peraturan Kepala BNN. Dalam pelaksanaan kewenangan tersebut, BNNK mendapat pembinaan teknis dan supervisi Pencegahan dan Pemberantasan Penyalahgunaan dan Peredaran Gelap Narkoba (P4GN) di bidang rehabilitasi dari BNN Provinsi. Tulisan ini juga menyimpulkan bahwa secara garis besarnya, BNNK Denpasar telah mengimplementasikan aturan mengenai rehabilitasi terhadap penyalah guna narkotika yang dapat dilihat dari pelaksanaan sosialisasi rehabilitasi gratis bagi pengguna narkotika, penyediaan tempat rehabilitasi, dan pemberian fasilitas transportasi bagi orang yang mengikuti program rehabilitasi di luar Bali.
\end{abstract}

Kata Kunci: Badan Narkotika Nasional, Kota Denpasar,Rehabilitasi, Penyalah Guna Narkotika

Abstract

TThis article discusses the authority of the Indonesian National Narcotics Board at the municipal level (BNNK) Denpasar in the application of rehabilitation for abuse of narcotics and analyzes the implementation of the rules on rehabilitation of abusers of narcotics by BNNK Denpasar. It is a legal research that combines the characteristics of normative legal research that uses statutory approach and the adoption of the model of socio-legal research relating to the implementation of field research that has been carried out at BNNK Denpasar in order to search for data, obtain information, and conduct interviews. The article concludes that the BNNK has the authority in the application of rehabilitation for abuse of narcotics as stipulated in the Regulation of the President of the Republic of Indonesia Number 23 Year 2010 on the National Narcotics Board and in some regulations issued by the Head of BNN. In the exercise of such authority, BNNK receives technical guidance and supervision of the Prevention and Combating Drug Abuse and Illicit Drugs (P4GN) in the field of rehabilitation from BNN at the provincial level. This writing also concludes that, to some extent, BNNK Denpasar has implemented rules regarding the rehabilitation of abusers of drugs as can be seen from the socialization of rehabilitation that is free for users of narcotics, provision of rehabilitation, and the provision of transport facilities for people who follow rehabilitation program outside Bali.

Keywords: The Indonesian National Narcotics Board, the Municipality (City) of Denpasar, Rehabilitation, Abusers of Narcotics

${ }^{1}$ Sagung Putri M.E Purwani adalah dosen pada Bagian Hukum Pidana Fakultas Hukum Universitas Udayana (FH UNUD). Sebelumnya ia pernah menjabat sebagai Sekretaris Bagian Hukum Pidana pada FH UNUD dan Koordinator Riset pada NPT Project Nuffic IDN-223 Strengthening Faculty of Law Udayana University.

2 Anak Agung Ngurah Yusa Darmadi adalah dosen pada Bagian Hukum Pidana FH UNUD. Sebelumnya ia pernah menjabat sebagai Ketua bagian Hukum Pidana FH UNUD.

${ }^{3}$ I Made Walesa Putra adalah dosen pada Bagian Hukum Pidana FH UNUD dan saat ini merupakan Ketua Unit Informasi dan Teknologi FH UNUD.

60 | Jurnal Ilmiah Fakultas Hukum Universitas Udayana 


\section{Pendahuluan}

\section{Latar belakang}

Badan Narkotika Nasional Kota (BNNK) Denpasar di tahun 2014 telah melakukan langkah nyata dalam pemberantasan penyalahgunaan narkotika yang masif dan terorganisir. Untuk menyongsong tahun 2015 sebagai tahun Indonesia bebas narkoba BNN Kota Denpasar melakukan sejumlah operasi, baik yang bersifat strategis maupun insidental. ${ }^{4}$ Operasi pemetaan kasus narkotika pun dilakukan di Kota Denpasar sejak bulan Mei 2014 di sejumlah lokasi melalui serangkaian kegiatan intelijen berupa observasi, surveillance dan undercover dengan hasil identifikasi orang, barang dan tempat. ${ }^{5}$

Secara strategis, BNN Kota Denpasar bekerja sama dengan pemerintah daerah dalam upaya mewujudkan misinya. Hal ini dapat dilihat dari penyelenggaraan diskusi kelompok terarah (Focus Group Discussion) oleh BNN Kota Denpasar yang mengundang perwakilan Satuan Kerja Perangkat Daerah (SKPD) Kota Denpasar. Melalui forum ini, para pimpinan SKPD diharapkan turut serta bergerak dalam pelaksanaan Pencegahan dan Pemberantasan Penyalahgunaan dan Peredaran Gelap Narkoba (P4GN) melalui kebijakan dan aturan yang mereka susun berkaitan dengan penyelamatan generasi muda dari bahaya narkoba. ${ }^{6}$

Mempertimbangkan eksistensi lembaga adat di Bali, khususnya Denpasar, untuk dijadikan sebagai salah satu media efektif untuk memberantas penyalahgunaan narkotika, BNN Kota Denpasar juga melibatkan peran pemuka adat. Sinergi antara instansi ini dengan Bendesa Pakraman diharapkan dapat membentengi masyarakat dari ancaman narkotika yang semakin mengkhawatirkan. ${ }^{7}$ Di lapangan, kolaborasi ini terlihat berjalan dengan baik. Petugas BNN Kota Denpasar dan Pacalang Desa Dauh Puri Kelod telah menyasar 4 komplek hunian kost di sekitar Jalan Pulau Sebatik dan Gang Sesapi di Jalan Teuku Umar Denpasar. ${ }^{9}$

BNN Kota Denpasar juga dengan gencar mengadakan sosialisasi P4GN untuk lingkungan pendidikan. Hal ini tampak dari intensitas sosialisasi yang dilakukan terhadap 261 siswa

\footnotetext{
4 Artikel, "Presiden SBY Luncurkan Gerakan Indonesia Bebas Narkoba 2015”, Antara News, 26 Juni 2011, http://www. antaranews.com/berita/264785/presiden-sby-luncurkan-gerakan-indonesia-bebas-narkoba-2015

5 Artikel, “Operasi Pemetaan Kasus Narkotika di Daerah Kota Denpasar”, Badan Narkotika Nasional Provinsi Bali, 18 Juni 2014, http://bali.bnn.go.id/data-kegiatan/operasi-pemetaan-kasus-narkotika-di-daerah-kota-denpasar/

6 Artikel, "BNN dan SKPD Kota Denpasar Ikut Selamatkan Generasi Muda” Badan Narkotika Nasional Kota Denpasar, 1April 2014, https://bnnkdenpasar.wordpress.com/2014/04/14/bnn-dan-skpd-kota-denpasar-ikut-selamatkan-generasi-muda/

7 Artikel, "BNNK Denpasar Mengajak Bendesa Pakraman Memerangi Narkoba”, Badan Narkotika Nasional Kota Denpasar, 11 Februari 2014. https://bnnkdenpasar.wordpress.com/2014/02/11/bnnk-denpasar-mengajak-bendesa-pakraman-memerangi-narkoba/

${ }^{8}$ Berdasarkan Pasal 1 angka 17 Peraturan Daerah Provinsi Bali Nomor 3 tahun 2001 tentang Desa Pakraman, Pacalang adalah satgas (satuan tugas) keamanan tradisional masyarakat Bali yang mempunyai wewenang untuk menjaga keamanan dan ketertiban wilayah, baik di tingkat banjar pakraman (adat) dan atau di wilayah desa pakraman (adat).

9 Artikel, "Penghuni Kost Ini Kaget BNN Denpasar Tes Urin Saat Dini Hari, Tribun Bali”, 27 Juni 2015, http://bali.tribunnews.com/2015/06/27/penghuni-kost-ini-kaget-bnn-denpasar-tes-urin-saat-dini-hari
} 


\section{KERTHA PATRIKA}

Volume 38, Nomor 1, Januari-April 2016

SMPN 1 Denpasar $^{10}$ dan sejumlah siswa dari SMP Negeri 9 Denpasar dan SMP Negeri 11 Denpasar. ${ }^{11}$

Operasi yang sangat strategis yang dilakukan BNN Kota Denpasar adalah pemeriksaan urine mendadak ke sejumlah tempat. Operasi yang menyasar lembaga pendidikan menengah pertama dan menengah atas dilakukan terhadap ratusan siswa-siswi SMPN 5 Denpasar, ${ }^{12}$ SMK Negeri 4 Denpasar, ${ }^{13}$ SMK Kertha Wisata, ${ }^{14}$ SMA Negeri $5,{ }^{15}$ dan SMA PGRI 2 Denpasar. ${ }^{16}$ Tidak hanya siswa-siswi, aparatur sipil negara juga tidak luput dari pemeriksaan mendadak. Sebanyak 51 orang pegawai Dinas Pendapatan Daerah Kota Denpasar juga langsung dites urine. ${ }^{17}$ Operasi mendadak BNN Kota Denpasar juga menyasar kalangan perusahaan swasta. Sebanyak 55 orang karyawan toko swalayan Tiara Dewata, ${ }^{18} 21$ karyawan kantor pemasaran mobil Astra Daihatsu Denpasar, dan 29 karyawan PT Agung Automall yang berlokasi di Jalan Cokroaminoto Denpasar, ${ }^{19}$ terpaksa mengikuti tes urine.

Selain itu, BNN Kota Denpasar juga melakukan kegiatan advokasi terhadap sejumlah lembaga, di antaranya pegawai Badan Perpustakaan, Arsip dan Dokumentasi (BPAD) Kota Denpasar ${ }^{20}$ dan aparat militer yang bernaung di bawah Komando Distrik Militer (Kodim) 1611/Badung. ${ }^{21}$ Advokasi juga diberikan kepada kalangan kelompok spiritual, yaitu kepada siswa Asram Paramadhama yang berada di bawah asuhan Rasa Acarya Prabu Raja Darmayasa. ${ }^{22}$

10 Artikel, "BNNK Denpasar Adakan Sosialisasi P4GN untuk Siswa SMPN 1", Badan Narkotika Nasional Kota Denpasar, 25 April 2014, https://bnnkdenpasar.wordpress.com/2014/04/25/bnnk-denpasar-adakan-sosialisasi-p4gn-untuk-siswa-smpn-1/

11 Artikel, "BNNK Denpasar Mensosialisasi P4GN Pada Siswa SMPN 9 \& 11 Denpasar", Badan Narkotika Nasional Kota Denpasar, 20 Februari 2014, https://bnnkdenpasar.wordpress.com/2014/02/20/72/

12 Artikel, "Diguga Suka Menikmati Sisha, 50 siswa SMPN 5 Denpasar Dites Urin oleh BPN, Suluh Bali, 20 September 2014, http://suluhbali.co/diduga-suka-menikmati-shisha-50-siswa-smpn-5-dites-urine-oleh-bnn/

13 Artikel, "BNN Kota Denpasar Menguji Urine Siswa SMKN 4 Denpasar", Badan Narkotika Nasional Kota Denpasar ,https://bnnkdenpasar.wordpress.com/2014/05/09/bnn-kota-denpasar-menguji-urine-siswa-smkn-4-denpasar/.

14 Artikel, "Siswa SMK Kertha Wisata Dites Urine, 18 Agustus 2014”, Dinas Pendidikan, Pemuda, dan Olah Raga Pemerintah Kota Denpasar, http://pendidikan.denpasarkota.go.id/index.php/baca-berita/8608/Siswa-SMK-Kertha-Wisata-Dites-Urine--

15 Artikel "Perangi Narkoba, Siswa SMAN 5 Denpasar Dites Urine Badan Narkotika Nasional Denpasar", Badan Narkotika Nasional Kota Denpasar, 21 April 2014, https://bnnkdenpasar.wordpress.com/2014/04/21/perangi-narkoba-siswa-sman-5denpasar-dites-urine/

${ }^{16}$ Artikel, “BNNTes Urine Siswa, Dua Positif”, BaliPost, 24Maret2014, http://balipost.com/read/headline/2014/03/24/7878/ bnn-tes-urine-siswa-dua-positif.html

17 Artikel, "BNNK Denpasar Mengetes Urine Pegawai Dispenda", Badan Narkotika Nasional Kota Denpasar, 10 Maret 2014, https://bnnkdenpasar.wordpress.com/2014/03/10/bnnk-denpasar-mengetes-urine-pegawai-dispenda/

18 Artikel, "55Karyawan Toko Swalayan Tiara Dewata Dites Urine”, Badan Narkotika Nasional Kota Denpasar, 5 Maret 2014, https://bnnkdenpasar.wordpress.com/2014/03/05/55-karyawan-toko-swalayan-tiara-dewata-dites-urine/

19 Artikel, "Dites BBNK Denpasar Karyawan Swhowroom Mobil Sempat Panik", Badan Narkotika Nasional Kota Denpasar, 8 April 2014, https://bnnkdenpasar.wordpress.com/2014/04/08/dites-bbnk-denpasar-karyawan-showroom-mobil-sempatpanik/

20 Artikel, “BNNK Denpasar Advokasi Pegawai BPAD”, Badan Narkotika Nasional Kota Denpasar , diakses dari https:// bnnkdenpasar.wordpress.com/2014/03/11/bnnk-denpasar-advokasi-pegawai-bpad/.

21 Artikel, “Anggota Kodim 1611 Badung mendapatkan Advokaso P4GN”, Badan Narkotika Nasional Kota Denpasar ,https://bnnkdenpasar.wordpress.com/2014/03/03/anggota-kodim-1611badung-mendapatkan-advokasi-p4gn/.

22 Artikel, "BNNK Denpasar Memberikan Advokasi P4GN pada siswa Ashram Paramadharma", Badan Narkotika Nasional Kota Denpasar, https://bnnkdenpasar.wordpress.com/2014/02/24/bnnk-denpasar-memberikan-advokasi-p4gn-pada-siswaashram-paramadhama/. 
Menarik sesungguhnya untuk mencermati langkah-langkah BNN Kota Denpasar tersebut apabila dikaitkan dengan Instruksi Presiden (Inpres) Nomor 12 Tahun 2011 tentang Pelaksanaan Kebijakan dan Strategi Nasional Pencegahan dan Pemberantasan Penyalahgunaan dan Peredaran Gelap Narkoba Tahun 2011-2015. Butir Pertama Inpres tersebut menyebut empat bidang yang menjadi cakupan kerja, yaitu pencegahan pemberdayaan masyarakat, rehabilitasi, dan pemberantasan. Dari ilustrasi di atas, langkah-langkah yang dilakukan BNN Kota Denpasar cenderung terfokus pada bidang pencegahan dan pemberdayaan masyarakat saja.

Sebagaimana digariskan di dalam Inpres tersebut, bidang pencegahan difokuskan pada upaya-upaya di antaranya menjadikan siswa/pelajar pendidikan menengah, mahasiswa, dan pekerja memiliki pola pikir, sikap, dan terampil menolak penyalahgunaan dan peredaran gelap narkoba. ${ }^{23}$ Adapun bidang pemberdayaan masyarakat menggariskan dilakukannya upaya menciptakan lingkungan pendidikan menengah dan lingkungan kerja yang bebas dari penyalahgunaan dan peredaran gelap narkoba. ${ }^{24}$ Fakta-fakta mengenai operasi BNN terhadap siswa sekolah menengah serta aparat kantor pemerintah dan karyawan swasta tentu mengindikasikan fokus terhadap kedua bidang ini. Dengan demikian, muncul pertanyaan mengenai bagaimanakah peran BNN Kota Denpasar berkaitan dengan bidang rehabilitasi dan pemberantasan.

Isu pemberantasan merupakan ranah lintas sektoral yang telah cukup banyak diteliti oleh sejumlah kalangan.Kebanyakan di antaranya menyoroti dan mencari kelemahan atau kesalahan yang dilakukan oleh penyidik/aparat penegak hukum, sehingga terkesan hanya menampilkan kegiatan represif saja. Adapun isu rehabilitasi ternyata tidak terlalu sering terekspose, sehingga amat menarik untuk dikaji.

Ada sejumlah penelitian yang melakukan kajian terhadap fungsi BNN di daerah dalam kaitannya dengan rehabilitasi. ${ }^{25}$ Penelitian yang dilakukan Musdalifah terhadap Balai Rehabilitasi BNN Tanah Merah Samarinda menyimpulkan bahwa salah satu faktor penghambat balai tersebut dalam merehabilitasi pecandu narkoba selain masih minimnya Sumber Daya Manusia, juga masih kurangnya sarana dan prasarana yang dibutuhkan untuk menjalankan program rehabilitasi pecandu narkoba. ${ }^{26}$

Penelitian yang dilakukan oleh Dani Krisnawati dan Niken Subekti Budi Utami, ${ }^{27}$ mer-

\footnotetext{
23 Butir Kedua, angka 1 huruf (a) dan (b) Instruksi Presiden Nomor 12 Tahun 2011 tentang Pelaksanaan Kebijakan dan Strategi Nasional Pencegahan dan Pemberantasan Penyalahgunaan dan Peredaran Gelap Narkoba Tahun 2011-2015.

24 Butir Kedua, angka 2 huruf (a) dan (b) Instruksi Presiden Nomor 12 Tahun 2011 tentang Pelaksanaan Kebijakan dan Strategi Nasional Pencegahan dan Pemberantasan Penyalahgunaan dan Peredaran Gelap Narkoba Tahun 2011-2015.

25 Ada juga penelitian di luar bidang hukum yang melakukan kajian mengenai isu ini, misalnya yang dilakukan oleh Heldy Chandra, Analisis Peranan Badan Narkotika Nasional Provinsi Dalam Pencegahan dan Penanggulangan Peredaran Narkotika Di Provinsi Sulawesi Selatan, Tesis, Program Studi Kesehatan Masyarakat, Program Pasca Sarjana Universitas Hasanuddin, Makassar, 2013, http://repository.unhas.ac.id:4001/digilib/files/disk1/46/--heldychand-2291-1-13-heldy-2.pdf

26 Musdalifah, Peran Balai Rehabilitasi Badan Narkotika Nasional (BNN) Tanah Merah Dalam Merehabilitasi Pecandu Narkoba Di Kota Samarinda, eJournal Ilmu Pemerintahan, 2015, 3 (2) : 718-730, Ilmu Pemerintahan, Fakultas Ilmu Sosial dan Ilmu Politik, Universitas Mulawarman

27 Dani Krisnawati dan Niken Subekti Budi Utami, "Pelaksanaan Rehabilitasi Bagi Pecandu Narkotika Pada Tahap Penyidikan Pasca Berlakunya Peraturan Bersama 7 (Tujuh) Lembaga Negara Republik Indonesia", Laporan Penelitian, Unit Penelitian Dan Pengabdian Kepada Masyarakat Fakultas Hukum Universitas Gadjah Mada (PPM-FH UGM), Yogyakarta (2014), https://
} 


\section{KERTHA PATRIKA}

Volume 38, Nomor 1, Januari-April 2016

ekomendasikan perlunya dilakukan sosialisasi Peraturan Bersama kepada masyarakat agar pecandu narkotika secara sukarela melaporkan dirinya ke Institusi Penerima Wajib Lapor (IPWL). Adapun IPWL dimaksud adalah pusat kesehatan masyarakat, rumah sakit, dan/atau lembaga rehabilitasi medis dan lembaga rehabilitasi sosial yang ditunjuk oleh Pemerintah. ${ }^{28}$

Meskipun terdapat beberapa institusi yang turut berperan penegakan hukum terhadap penyalahgunaan narkotika masih bermasalah yaitu belum ada upaya pembinaan khusus terhadap pengguna sebagai korban. Saat ini masyarakat masih beranggapan bahwa para pengguna adalah penjahat.Secara normatif Pasal 127 ayat (3) Undang-Undang Nomor 35 Tentang Narkotika (UU Narkotika), menentukan bahwa "Dalam hal penyalah guna sebagaimana dimaksud pada ayat (1) dapat dibuktikan atau terbukti sebagai korban penyalahgunaan Narkotika, Penyalah Guna tersebut wajib menjalani rehabilitasi medis dan rehabilitasi sosial."

Menjadi penting memahami konsep kejahatan tanpa korban (crime without victim) terhadap penyalahgunaan narkotika, yang mendalilkan bahwa korban dari kejahatan ini adalah dirinya sendiri, atau pelaku yang sekaligus menjadi korban. ${ }^{29}$ Seorang penyalah guna narkotika dan pecandu harus dijauhkan dari stigma pidana dan diberikan perawatan. Upaya penanggulangan penyalahgunaan narkotika yang sering diabaikan oleh aparat penegak hukum di Indonesia, yaitu adanya upaya rehabilitasi. Model pemidanaan terhadap penyalah guna narkotika sampai saat ini masih menempatkan penyalah guna sebagai pelaku tindak pidana (kriminal) sehingga upaya rehabilitasi sering terabaikan. ${ }^{30}$

UU Narkotika membedakan definisi antara penyalah guna dan pecandu. Penyalah guna didefinisikan sebagai orang yang menggunakan Narkotika tanpa hak atau melawan hukum sedangkan pecandu Narkotika adalah orang yang menggunakan atau menyalahgunakan Narkotika dan dalam keadaan ketergantungan pada Narkotika, baik secara fisik maupun psikis. ${ }^{31}$

Baik penyalah guna narkotika maupun pecandu narkotika sesungguhnya sama-sama menggunakan atau menyalahgunakan narkotika tanpa hak atau melawan hukum. Hanya saja pecandu narkotika mempunyai karakteristik tersendiri, yakni adanya ketergantungan pada narkotika, baik secara fisik maupun psikis, karenanya bagi pecandu hanya dikenakan tindakan berupa kewajiban menjalani rehabilitasi medis dan rehabilitasi sosial. Berdasarkan Pasal 127 Undang-Undang Narkotika, penyalah guna narkotika bisa menjadi subyek yang dapat dipidana

repository.ugm.ac.id/97187/1/Pelaksanaan\%20Rehabilitasi\%20Bagi\%20Pecandu\%20Narkotika\%20Pada\%20Tahap\%20Penyidikan\%20Pasca\%20Berlakunya\%20Peraturan\%20Bersama\%207\%20\%28Tujuh\%29\%20Lembaga\%20Negara\%20Republik\%20 Indonesia_2.pdf

28

Pasal 1 angka 2 dan Pasal 4 ayat (2) Peraturan Pemerintah Republik Indonesia Nomor 25 Tahun 2011 Tentang Pelaksanaan Wajib Lapor Pecandu Narkotika. Lihat juga Peraturan Menteri Kesehatan Republik Indonesia Nomor 50 Tahun 2015 Tentang Petunjuk Teknis Pelaksanaan Wajib Lapor dan Rehabilitasi Medis Bagi Pecandu, Penyalahguna, Dan Korban Penyalahgunaan Narkotika

29 Weda Darma Made, 1999, Kronik dalam Penegakan Hukum Pidana, Guna Widya, Jakarta, h. 80

30 Artikel Hasil Kajian "Membangun Paradigma Dekriminalisasi Korban Pengguna Narkoba”, Gepenta, http://www.gepenta.com/a,public-m,dinamic-s, detail-ids,12-id,51-lang,id-c,artikel-t,Membangun+Paradigma+Dekriminalisasi+Korban+Penggu na+Narkoba-.phpx, diakses tanggal 8 November 2012.

31 Pasal 1 angka 13 dan 15 Undang-Undang Nomor 35 Tentang Narkotika. 
kecuali dapat dibuktikan atau terbukti sebagai korban penyalahgunaan narkotika, apabila itu terjadi maka penyalah guna tersebut wajib menjalani rehabilitasi medis dan rehabilitasi sosial.

\section{Rumusan Masalah}

Berdasarkan latar belakang di atas, maka terdapat dua rumusan masalah yang dibahas, yaitu:

1. Bagaimanakah kewenangan Badan Narkotika Nasional Kota (BNNK) dalam penerapan rehabilitasi bagi penyalah guna Narkotika?

2. Bagaimanakah implementasi aturan mengenai rehabilitasi terhadap penyalah guna narkotika oleh BNN Kota Denpasar?

\section{Tujuan Penulisan}

Penelitian ini pada dasarnya bertujuan untuk menganalisis kewenangan Badan Narkotika Nasional Kota (BNNK) dalam penerapan rehabilitasi bagi penyalahgunaan Narkotika serta secara spesifik untuk mengkaji implementasi aturan mengenai rehabilitasi terhadap penyalah guna narkotika oleh BNN Kota Denpasar.

\section{Metode Penelitian}

Analisis yang dilakukan terhadap isu hukum yang diketengahkan di dalam rumusan masalah pertama dari tulisan ini menunjukkan karakteristik penelitian hukum normatif.Pendekatan peraturan perundang-undangan (statute approach) pun digunakan dalam menelusuri sejumlah undang-undang termasuk undang-undang ratifikasi terhadap perjanjian internasional yang relevan, peraturan pemerintah, peraturan presiden, peraturan menteri, dan peraturan Kepala BNN yang terkait dengan kewenangan BNN dalam melakukan rehabilitasi Penyalah Guna Narkotika.

Adapun pembahasan terhadap rumusan masalah kedua cenderung mengadopsi model socio-legal research, yang mencoba menemukan kebenaran dengan tetap bertumpu pada premis normatif dengan fokus kajiannya pada esensi hukum yang tertuang dalam bentuk norma-norma, yang kemudian dihubungkan dengan kenyataan yang terjadi di lapangan. Secara sederhana dapat digambarkan bahwa penelitian ini mengkombinasikan teori hukum dengan data faktual. ${ }^{32}$

Ada dua teknik penelusuran bahan hukum, informasi, dan data yang dilakukan. Pertama,

${ }^{32}$ Lihat Victor Immanuel W. Nalle "'The Relevance of Socio Legal-Studies in Legal Science”, Mimbar Hukum, Volume 27 Nomor 1, Februari 2015, h.184. mimbar.hukum.ugm.ac.id/index.php/jmh/article/download/522/362 . 


\section{KERTHA PATRIKA}

Volume 38, Nomor 1, Januari-April 2016

dalam rangka menelusuri bahan hukum primer berupa peraturan perundang-undangan terkait, peneliti melakukan studi kepustakaan yang bersifat tematik, yaitu menelusuri peraturan yang relevan dengan isu narkotika, rehabilitasi, dan tindak pidana di yang berlaku Indonesia. Kedua, untuk memperoleh informasi dan data, peneliti melakukan penelitian ke BNN Kota Denpasar. Secara teknis, teknik wawancara (interview) dilakukan terhadap informan yang merupakan pejabat BNN Kota Denpasar dengan menggunakan teknik snow bowling. Peneliti juga menggunakan data yang diperoleh dari BNN Kota Denpasar sebagai ilustrasi dalam menganalisis isu yang dikaji. Seluruh bahan hukum, informasi, dan data kemudian diolah dan dianalisis secara kritis analitis dan disajikan secara deskriptif analitis.

\section{HASIL DAN PEMBAHASAN}

1. Kewenangan Badan Narkotika Nasional Kota dalam Penerapan Rehabilitasi bagi Penyalah Guna Narkotika

Untuk membahas isu yang diangkat dalam rumusan masalah ini, maka uraian berikut akan dibagi menjadi tiga bagian. Bagian pertama, akan membahas tentang pidana penjara dan rehabilitasi sebagai tindakan yang sama-sama dapat diberikan terhadap penyalahguna narkotika. Selanjutnya, bagian kedua akan membahas kewenangan Badan Narkotika Nasional (BNN) secara umum. Bagian terakhir akan memfokuskan pada deskripsi mengenai Kewenangan Badan Narkotika Nasional Kota untuk menerapkan rehabilitasi bagi penyalahgunaan Narkotika.

\section{a. Penjatuhan Pidana Penjara atau Rehabilitasi terhadap Penyalah Guna Narkotika}

Rehabilitasi dan penjatuhan pidana penjara kerap kali dipandang sebagai dua hal yang berseberangan. Para pendukungnya rehabilitasi senantiasa mengemukakan sejumlah alasan mengapa rehabilitasi jauh lebih baik dibandingkan dengan penjatuhan pidana penjara, demikian pula sebaliknya.

Artikel berjudul Punishment Fails, Rehabilitation Works, yang ditulis oleh James Gilligan, profesor dari New York University memberikan ilustrasi betapa hukuman penjara tidak lagi efektif di Amerika Serikat. ${ }^{33}$ Bahkan rehabilitasi yang telah sekian dekade tidak diterima sebagai suatu teori penghukuman (theory of punishment) telah diusung oleh Supreme Court di Amerika Serikat pada kasus Graham v. Florida di tahun 2010.34

Penggunaan rehabilitasi dalam pemidanaan kasus narkotika sesungguhya telah lama men-

\footnotetext{
33 James Gilligan. Punishment Fails, Rehabilitation Works. New York Times, December 19, 2012, Http://Www.Nytimes. Com/Roomfordebate/2012/12/18/Prison-Could-Be-Productive/Punishment-Fails-Rehabilitation-Works.

${ }^{34}$ Allegra M. Mcleod, Decarceration Courts: Possibilities and Perils of a Shifting Criminal Law, The Georgetown Law Journal, Vol. 100:1587, 2012, h.1604, Http://Georgetownlawjournal.Org/Files/2012/06/Mcleod.Pdf
}

66 | Jurnal Ilmiah Fakultas Hukum Universitas Udayana 
Implementasi Pengaturan Rehabilitasi Penyalah Guna Narkotika Oleh Badan Narkotika Nasional Kota Denpasar Sagung Putri M. E. Purwani, Anak Agung Ngurah Yusa Darmadi, I Made Walesa Putra

jadi komitmen dari masyarakat internasional. Single Convention in Narcotic Drugs yang telah diratifikasi oleh Indonesia melalui Undang-Undang Nomor 8 Tahun $1976^{35}$ merupakan instrumen yang memberikan legitimasi bagi pemberian rehabilitasi terhadap pengguna narkotika.

Pengaturan mengenai ketentuan-ketentuan pidana (penal provisons) sebagaimana tertuang di dalam Pasal 36 huruf b Single Convention in Narcotic Drugs menyatakan sebagai berikut:

"Notwithstanding the preceding subparagraph, when abusers of drugs have committed such offences, the Parties may provide, either as an alternative to conviction or punishment or in addition to conviction or punishment, that such abusers shall undergo measures of treatment, education, after-care, rehabilitation and social reintegration in conformity with paragraph 1 of article 38 "

Jelas dinyatakan dalam ketentuan tersebut bahwa negara Pihak, dalam hal ini termasuk Indonesia, dapat memberikan rehabilitasi sebagai salah satu alternatif hukuman bagi para penyalahguna narkotika.

Selanjutnya, Pasal 38 ayat (1) Single Convention in Narcotic Drugs yang mengatur isu tentang perlakuan-perlakuan terhadap penyalah guna narkotika (measures against the abuse of Drugs) menyatakan sebagai berikut: "The Parties shall give special attention to and take all practicable measures for the prevention of abuse of drugs and for the early identification, treatment, education, after-care, rehabilitation and social reintegration of the persons involved and shall co-ordinate their efforts to these ends." Secara tegas, ketentuan ini menggariskan bahwa negara Pihak dalam konvensi ini harus memberikan perhatian khusus untuk dan mengambil semua langkah praktis, termasuk salah satunya untuk melakukan rehabilitasi terhadap orang-orang yang terlibat. Lebih jauh, ayat (2) dari pasal tersebut juga menentukan bahwa negara pihak harus sedapat mungkin mengupayakan pelatihan bagi petugas rehabilitasi bagi penyalah guna narkotika.

Semangat untuk mengedepankan rehabilitasi juga tercermin pada komitmen pemerintah negara-negara di tingkat regional Asia Tenggara. Forum ASEAN Ministerial Meeting on Drug Matters (AMMDM) di akhir tahun 2014 mengusulkan agarimplementasi rehabilitasi di ASEAN dimaksimalkan melalui peningkatan akses dan fasilitas layanan rehabilitasi untuk para penyalah guna narkoba. Selain itu, ASEAN menilai perlu adanya standarisasi dalam mengaktualisaskan berbagai aksi baik itu dalam konteks pencegahan maupun rehabilitasi. ${ }^{36}$

Istilah rehabilitasi bukanlah hal asing dalam konteks hukum nasional di Indonesia. Rehabilitasi merupakan salah satu asas dalam Sistem Peradilan Pidana di Indonesia berdasarkan

\footnotetext{
${ }^{35}$ Kementerian Luar Negeri RI, Daftar Perjanjian Internasional(Tersimpan Di Kementerian Luar Negeri, Republik Indonesia), http://treaty.kemlu.go.id/index.php/treaty/index?fullPage=1\&Treaty_page=213\&sort=treaty_title.desc

${ }^{36}$ ASEAN Sepakat Perlu Paradigma Baru Penanganan Narkoba Majalah Sinar, Edisi XI-2014, h.6-7, http://103.3.70.3/ portal/_uploads/post/2015/07/06/Majalah_Sinar_Edisi_XI_2014.pdf.
} 


\section{KERTHA PATRIKA}

Volume 38, Nomor 1, Januari-April 2016

Undang-Undang Nomor 8 tahun 1981 maupun dalam pembahasan teoritik mengenai peniadaan hukuman dan pengurangan hukuman. ${ }^{37}$

UU Narkotika merupakan instrumen hukum yang digunakan untuk menanggulangi berbagai masalah terkait narkotika. Pasal 1 angka 15 UU Narkotika menyatakan bahwa penyalah guna adalah orang yang menggunakan narkotika tanpa hak atau melawan hukum. ${ }^{38}$ Adapun penyalahgunaan narkotika dapat diartikan sebagai tindakan atau perbuatan yang tidak sebagaimana mestinya (menyimpang atau bertentangan dengan yang seharusnya) yang mempergunakan narkotika secara berlebihan (overdosis) sehingga membahayakan diri sendiri, baik secara fisik maupun psikis. ${ }^{39}$

Undang-undang tersebut membagi pengguna narkotika menjadi 2 (dua) kategori, yaitu pengguna narkotika terhadap orang lain ${ }^{40}$ dan pengguna narkotika untuk diri sendiri. ${ }^{41}$ Pengguna narkotika terhadap orang lain adalah setiap orang yang tanpa hak atau melawan hukum memberikan narkotika untuk digunakan oleh orang lain. Melawan hukum berarti dengan tanpa hak atau ijin dari pihak yang berwenang. Sedangkan pengguna narkotika untuk diri sendiri adalah penggunaan narkotika yang dilakukan oleh seseorang tanpa hak atau melawan hukum. Apabila orang yang bersangkutan dapat dibuktikan atau terbukti sebagai korban penyalahgunaan narkotika, maka harus menjalani rehabilitasi medis maupun rehabilitasi sosial dan masa rehabilitasinya akan diperhitungkan sebagai masa menjalani hukuman. ${ }^{42}$

Selanjutnya, pengertian korban penyalahgunaan narkotika menurut Penjelasan Pasal 54 UU Narkotika yaitu seseorang yang tidak sengaja menggunakan narkotika karena dibujuk, diperdaya, ditipu, dipaksa, dan/atau diancam untuk menggunakan narkotika. Berdasarkan tingkat keterlibatan korban dalam terjadinya kejahatan, korban penyalahgunaan narkotika termasuk dalam tipologi false victims, yaitu pelaku yang menjadi korban karena dirinya sendiri, untuk itu pertanggungjawaban sepenuhnya terletak pada korban sekaligus sebagai pelaku kejahatan.

Berbagai rangkaian tindakan untuk menyalahgunakan narkotika tersebut dapat diancam tiga pasal sekaligus, yakni :

a. Pasal 114 ayat (1) UU Narkotika dalam hal perbuatan menawarkan untuk dijual, menjual, membeli, menjadi perantara dalam jual beli, menukar, menyerahkan, atau menerima Narkotika Golongan I dengan ancaman hukuman minimum 5 dan maksimum 20 tahun.

b. Pasal 112 ayat (1) UU Narkotika dalam hal perbuatan memiliki, menyimpan, menguasai, atau menyediakan Narkotika Golongan I bukan tanaman dengan ancaman hukuman mini-

\footnotetext{
37 Tina Asmarawati. 2015. Pidana dan Pemidanaan dalam Sistem Hukum di Indonesia (Hukum Penitensier).Deepublish. Yogyakarta. h. 157, 212.

${ }^{38}$ Lihat juga bagian 1.1

39 A. W. Widjaya,1985, Masalah kenakalan Remaja dan Penyalahgunaan Narkotika, Armico, Bandung, h. 13.

40 Pasal 116, Pasal 121, dan Pasal 126 Undang-Undang Nomor 35 Tentang Narkotika

41 Pasal 127 Undang-Undang Nomor 35 Tentang Narkotika.

42 Syamsudin, Aziz, 2011, Tindak Pidana Khusus, Sinar Grafika, Jakarta.
} 
Implementasi Pengaturan Rehabilitasi Penyalah Guna Narkotika Oleh Badan Narkotika Nasional Kota Denpasar

mum 4 tahun dan maksimum 12 tahun.

c. Pasal 127 ayat (1) huruf a UU Narkotika dalam hal penyalah guna Narkotika Golongan I bagi diri sendiri dengan ancaman hukuman maksimum 4 tahun

Penting kiranya memberikan deskripsi mengenai norma yang tertuang di dalam Pasal 127 UU Narkotika yang mencantumkan ancaman pidana penjara bagi penyalah guna Narkotika yang menentukan sebagai berikut:

(1) Setiap Penyalah Guna:

a. Narkotika Golongan I bagi diri sendiri dipidana dengan pidana penjara paling lama 4 (empat) tahun;

b. Narkotika Golongan II bagi diri sendiri dipidana dengan pidana penjara paling lama 2 (dua) tahun; dan

c. Narkotika Golongan III bagi diri sendiri dipidana dengan pidana penjara paling lama 1 (satu) tahun.

(2) Dalam memutus perkara sebagaimana dimaksud pada ayat (1), hakim wajib memperhatikan ketentuan sebagaimana dimaksud dalam Pasal 54, Pasal 55, dan Pasal 103

(3) Dalam hal Penyalah Guna sebagaimana dimaksud pada ayat (1) dapat dibuktikan atau terbukti sebagai korban penyalahgunaan Narkotika, Penyalah Guna tersebut wajib menjalani rehabilitasi medis dan rehabilitasi sosial.

Ketentuan-ketentuan di atas perlu dikaitkan dengan norma yang tertuang di dalam Pasal 54 UU Narkotika yang secara tegas menyatakan bahwa "Pecandu Narkotika dan korban penyalahgunaan Narkotika wajib menjalani rehabilitasi medis dan rehabilitasi sosial.” Adapun Rehabilitasi medis Pecandu Narkotika dilakukan di rumah sakit ${ }^{43}$ sedangkan Rehabilitasi sosial diselenggarakan baik oleh instansi pemerintah maupun oleh masyarakat. ${ }^{44}$ Selain itu, UU Narkotika memberi ruang alternatif bagi penyembuhan Pecandu Narkotika melalui pendekatan keagamaan dan tradisional yang diselenggarakan oleh instansi pemerintah atau masyarakat. ${ }^{45}$

Sejumlah pihak berpendapat bahwa penerapan hukuman pidana berupa pidana penjara bagi penyalah guna narkotika terbukti tidak berhasil, karena angka penyalah guna narkotika yang masuk lembaga pemasyarakatan setiap tahunnya semakin meningkat. ${ }^{46}$ Faktor terpenting dalam upaya penanggulangan penyalahgunaan narkotika yang sering diabaikan terutama oleh aparat penegak hukum di Indonesia adalah adanya upaya rehabilitasi. Tampak jelas bahwa model pemidanaan terhadap penyalah guna narkotika sampai sekarang ini masih menempatkannya sebagai pelaku tindak pidana (kriminal) sehingga upaya rehabilitasi sering terabaikan.

\footnotetext{
43 Pasal 56 ayat (1) Undang-Undang Nomor 35 Tentang Narkotika.

44 Pasal 58 Undang-Undang Nomor 35 Tentang Narkotika.

45 Pasal 57 Undang-Undang Nomor 35 Tentang Narkotika

46 Psikomedia.com, Ketua DPR: Pengguna Narkotika Lebih Baik Direhabilitasi Daripada Dipenjara, http://foblog.psikomedia.com/read/Berita-dan-Politik/29805/ketua-dpr--pengguna-narkotika-lebih-baik-direhabilitasi-daripada-dipenjara/, diakses tanggal 26 January 2014. 


\section{KERTHA PATRIKA}

Volume 38, Nomor 1, Januari-April 2016

Jaminan rehabilitasi medis dan sosial bagi korban penyalahgunaan narkotika sangat tergantung terhadap putusan hakim yang memeriksa perkara korban penyalahgunaan narkotika, kendati demikian dalam prakteknya korban penyalahgunaan narkotika bisa didakwa sebagai penyalah guna. Sebagai contoh, pengguna narkotika karena kecanduan harus membeli Narkotika Golongan I bukan tanaman secara melawan hukum dan tanpa hak, kemudian narkotika tersebut dimiliki atau dikuasai dan setelah itu digunakan untuk dirinya sendiri.

Bahkan dalam penentuan sanksi sering ada disparitas putusan hakim terhadap pemakai. Hukuman untuk pemakai yang satu bisa berupa sanksi penjara sedangkan pemakai yang lain dapat dikenakan rehabilitasi. Perbedaan putusan inilah terkadang menyulitkan BNN untuk menentukan sikap. ${ }^{47}$

Pengenaan sanksi rehabilitasi medis dan/atau rehabilitasi sosial, sesungguhnya sejalan dengan Surat Edaran Mahkamah Agung (SEMA) Nomor 3 Tahun 2011 tentang Penempatan Korban Penyalahgunaan Narkotika di dalam Lembaga Rehabilitasi Medis dan Rehabilitasi Sosial. SEMA ini menekankan agar hakim memberikan perintah penempatan pada lembaga rehabilitasi sosial dan medik baik dalam bentuk penetapan ataupun putusan bagi penyalah guna, korban penyalahgunaan dan pecandu Narkotika. ${ }^{48}$

Surat Edaran Mahkamah Agung tersebut perlu menjadi pertimbangan hakim dalam memutus suatu persoalan hukum terhadap pengguna narkotika. Sekiranya Hakim harus menunjuk secara tegas dan jelas tempat rehabilitasi yang terdekat dalam amar putusannya dan untuk menjatuhkan lamanya proses rehabilitasi, hakim harus sungguh-sungguh mempertimbangkan kondisi atau taraf kecanduan terdakwa sehingga wajib diperlukan adanya keterangan ahli dan sebagai standar dalam proses terapi dan rehabilitasi.

Penjatuhan pidana rehabilitasi terhadap pengguna narkotika yang telah dibuktikan atau terbukti sebagai korban penyalahgunaan narkotika secara implisit memiliki makna dan hakikat dari pembaharuan hukum pidana dilihat dari sudut pendekatan kebijakan sosial, yaitu upaya untuk mengatasi masalah-masalah sosial (termasuk masalah kemanusiaan) dalam rangka mencapai tujuan nasional (kesejahteraan masyarakat). Tindakan rehabilitasi baik berupa rehabilitasi medis maupun rehabilitasi sosial terhadap korban penyalahgunaan narkotika tentu diharapkan dapat menjadikan hukum positif menjadi lebih baik.

Penting juga diklarifikasi bahwa rehabilitasi sesungguhnya bukan semata-mata merupakan bentuk sanksi alternatif yang dijatuhkan hakim pasca persidangan tindak pidana narkotika. Bahkan tersangka dan/atau terdakwa penyalahgunaan Narkotika yang sedang menjalani proses penyidikan, penuntutan, dan persidangan di pengadilan pun diberikan pengobatan, perawatan dan pemulihan dalam lembaga rehabilitasi. ${ }^{49}$

\footnotetext{
47 Dani Krisnawati dan Eddy O.S. Hiariej, 2006, Bunga Rampai Hukum Pidana Khusus, Pena Pundi Aksara, Jakarta, h. 99.

${ }^{48}$ Surat Edaran Mahkamah Agung (SEMA) Nomor 3 Tahun 2011 tentang Penempatan Korban Penyalahgunaan Narkotika di dalam Lembaga Rehabilitasi Medis dan Rehabilitasi Sosial, Butir 6 dan 7.

49 Lihat Pasal 3 ayat (1) Peraturan Kepala Badan Narkotika Nasional Nomor 11 Tahun 2014 Tentang Tata Cara Penan-
} 


\section{b. Badan Narkotika Nasional sebagai Salah Satu Institusi yang Berwenang di Bidang Pen- anggulangan Narkotika}

Selama puluhan dekade, Kepolisian Negara Republik Indonesia merupakan institusi yang memiliki tugas memberantas penyalahgunaan Narkotika. Kewenangan ini diberikan sesuai dengan Pasal 15 ayat (1) huruf c Undang-Undang Nomor 2 Tahun 2002 tentang Kepolisian Negara Republik Indonesia, dinyatakan bahwa salah satu wewenang kepolisian yakni mencegah dan menanggulangi tumbuhnya penyakit masyarakat. Bagian Penjelasan atas ketentuan tersebut selanjutnya memberikan klarifikasi yang menyatakan bahwa salah satu hal yang dimaksud dengan penyakit masyarakat adalah penyalahgunaan obat dan narkotika.

Penyalahgunaan narkotika yang semakin meluas dan mengkhawatirkan serta isu mengenai upaya penanggulangannya kemudian menjadi perdebatan di kalangan para ahli hukum mengenai perlu tidaknya membentuk suatu lembaga berskala nasional yang diberikan kewenangan untuk menanggulangi kasus-kasus penyalahgunaan narkotika. Atas dasar itu, Pemerintah menerbitkan Keputusan Presiden Nomor 17 Tahun 2002 tentang Badan Narkotika Nasional (BNN). Perkembangan keorganisasian BNN kemudian diatur lebih lanjut di dalam Peraturan Presiden Nomor 83 Tahun 2007 tentang Badan Narkotika Nasional, Badan Narkotika Provinsi, dan Badan Narkotika Kabupaten/Kota. ${ }^{50}$

Eksistensi keorganisasian BNN saat ini didasarkan pada Pasal 149 huruf a Undang-Undang Nomor 35 Tentang Narkotika dan Peraturan Presiden Republik Indonesia Nomor 23 Tahun 2010 tentang Badan Narkotika Nasional. Pasal 1 ayat (1) peraturan presiden tersebut menentukan bahwa lembaga ini dikualifikasikan sebagai lembaga pemerintah non kementerian yang berkedudukan di bawah dan bertanggung jawab kepada Presiden melalui koordinasi Kepala Kepolisian Negara Republik Indonesia. Lembaga ini memiliki struktur vertikal ke bawah hingga Provinsi dan Kabupaten/Kota.

BNN mempunyai tugas yang cukup banyak. Tugasnya yang paling utama adalah dalam hal perumusan dan pelaksanaan kebijakan kebijakan nasional mengenai pencegahan dan pemberantasan penyalahgunaan dan peredaran gelap Narkotika dan Prekursor Narkotika serta sekaligus mencegah dan memberantasnya. ${ }^{51}$ Selain tugas utama tersebut, BNN memiliki fungsi melakukan koordinasi dengan kepolisian, meningkatkan kemampuan lembaga rehabilitasi medis

\footnotetext{
ganan Tersangka dan/atau Terdakwa Pecandu Narkotika dan Korban Penyalahgunaan Narkotika ke dalam Lembaga Rehabilitasi. http://www.bnn.go.id/portal/_uploads/post/2014/04/28/PERKA_BNN_11_THN_2014.pdfdan Pasal 2 huruf c Peraturan Bersama Ketua Mahkamah Agung Republik Indonesia, Menteri Hukum dan Hak Asasi Manusia Republik Indonesia, Menteri Kesehatan Republik Indonesia, Menteri Sosial Republik Indonesia, Jaksa Agung Republik Indonesia, Kepala Kepolisian Negara Republik Indonesia, Kepala Badan Narkotika Nasional Republik Indonesia Tentang Penanganan Pecandu Narkotika dan Korban Penyalahgunaan Narkotika ke dalam Lembaga Rehabilitasi Nomor: PERBER/01/III/2014/BNN, http://bali.bnn.go.id/cms/wp-content/ uploads/2014/06/PERATURAN-BERSAMA-KETUA-MAHKAMAH-AGUNG-DKK.pdf dan http://www.pa-karawang.go.id/uploads/arsip/64PERATURAN_BERSAMA_2014.pdf

50 Pasal 66 Undang-Undang Nomor 35 Tahun 2009 Tentang Narkotika.

51 Pasal 2 ayat (1) huruf a dan b Peraturan Presiden Republik Indonesia Nomor 23 Tahun 2010 tentang Badan Narkotika Nasional
} 


\section{KERTHA PATRIKA}

Volume 38, Nomor 1, Januari-April 2016

dan rehabilitasi sosial pecandu Narkotik, memberdayakan masyarakat dan sekaligus memantau, mengarahkan, dan meningkatkan kegiatan masyarakat dalam pencegahan penyalahgunaan dan peredaran gelap Narkotika dan Prekursor Narkotika. ${ }^{52}$

Secara lebih luas, BNN juga diberikan tugas untuk melakukan kerja sama lintas negara dalam isu narkotika, mengembangkan laboratorium Narkotika dan Prekursor Narkotika, melaksanakan administrasi penyelidikan dan penyidikan tehadap perkara penyalahgunaan dan peredaran gelap Narkotika dan Prekursor Narkotika, serta membuat laporan tahunan mengenai pelaksanaan tugas dan wewenang $\mathrm{BNN}^{53}$ Khusus dalam melaksanakan tugas pemberantasan penyalahgunaan dan peredaran gelap Narkotika, BNN diberikan kewenangan untuk melakukan penyelidikan dan penyidikan penyalahgunaan dan peredaran gelap Narkotika dan Prekursor Narkotika. ${ }^{54}$

\section{c. Kewenangan Penerapan Rehabilitasi Bagi Penyalahguna Narkotika oleh Badan Narko- tika Nasional Kota}

Badan Narkotika Nasional (BNN) merupakan lembaga yang diberikan tugas dan fungsi di bidang rehabilitasi pengguna narkotika. Pasal 2 ayat (1) huruf d menyatakan bahwa BNN diberikan tugas untuk meningkatkan kemampuan lembaga rehabilitasi medis dan rehabilitasi sosial pecandu Narkotika, baik yang diselenggarakan oleh pemerintah maupun masyarakat. Untuk melaksanakan tugas tersebut, BNN berfungsi dalam penyusunan dan perumusan kebijakan teknis rehabilitasi, pelaksanaan kebijakan nasional dan kebijakan teknis P4GN di bidang rehabilitasi, pengoordinasian instansi pemerintah terkait maupun komponen masyarakat dalam pelaksanaan rehabilitasi bagi penyalahguna dan/atau pecandu narkotika di tingkat pusat dan daerah, pengkoordinasian peningkatan kemampuan lembaga rehabilitasi medis dan rehabilitasi sosial pecandu narkotika, serta peningkatan kemampuan lembaga rehabilitasi penyalahguna dan/ atau pecandu narkotika. ${ }^{55}$

Hingga saat ini BNN telah mendirikan satu Balai Besar Rehabilitasi BNN yang berpusat di Lido Sukabumi, 1 Loka Rehabilitasi di Batam, 1 Balai Rehabilitasi Baddoka Makassar dan 1 Balai Rehabilitasi Tanah Merah di Samarinda. ${ }^{56}$ Saat ini, ada sejumlah lembaga yang memi-

\footnotetext{
52 Pasal 2 ayat (1) huruf c, d, e, dan f Peraturan Presiden Republik Indonesia Nomor 23 Tahun 2010 tentang Badan Narkotika Nasional.

53 Pasal 2 ayat (1) huruf g, h, i, dan j Peraturan Presiden Republik Indonesia Nomor 23 Tahun 2010 tentang Badan Narkotika Nasional.

54 Pasal 71 Undang-Undang Nomor 35 Tahun 2009 Tentang Narkotika dan Pasal 4 Peraturan Presiden Republik Indonesia Nomor 23 Tahun 2010 tentang Badan Narkotika Nasional. Nasional.

55 Pasal 3 huruf d, e, 1, m, dan n Peraturan Presiden Republik Indonesia Nomor 23 Tahun 2010 tentang Badan Narkotika

56 Keputusan Kepala Badan Narkotika Nomor: KEP/422/XII/KA OT.01/ 2015 /BNN Tentang Road Map Reformasi Birokrasi Badan Narkotika Nasional Tahun 2015-2019.h. 15, diakses dari http://www.bnn.go.id/_multimedia/document/20160304/ road_map_untuk_biro_umum-20160304134915.pdf
} 
Implementasi Pengaturan Rehabilitasi Penyalah Guna Narkotika Oleh Badan Narkotika Nasional Kota Denpasar Sagung Putri M. E. Purwani, Anak Agung Ngurah Yusa Darmadi, I Made Walesa Putra

liki kewenangan di bidang rehabilitasi. Sejumlah pihak memandang bahwa koordinasi dan pola pendekatan dalam penanggulangan penyalahgunaan Narkotika di Indonesia belum terpadu karena dan instansi masih terlihat bekerja sendiri-sendiri. Lembaga-lembaga yang fungsinya berkaitan dengan penegakan hukum di bidang tindak pidana narkotika dan aspek kesehatannya menyadari bahwa perlu dilakukan semacam penyamaan persepsi sekaligus kohesivitas dalam tindakan pemberian rehabilitasi. Hal tersebut kemudian melandasi dibentuknya Peraturan bersama tujuh lembaga negara tertanggal 11 Maret 2015 yang disusun dengan tujuan untuk terlaksananya proses rehabilitasi medis dan rehabilitasi sosial di tingkat penyidikan, penuntutan, persidangan dan pemidanaan secara sinergis dan terpadu.

Sesuai dengan Pasal 24 huruf (b) Peraturan Kepala BNN Nomor 3 Tahun 2015 Tentang Organisasi dan Tata Kerja BNN Provinsi dan BNN Kabupaten/Kota, BNN Kota menyelenggarakan fungsi pelaksanaan kebijakan teknis di bidang pencegahan, pemberdayaan masyarakat, rehabilitasi dan pemberantasan dalam wilayah Kota. Seksi rehabilitasi merupakan struktur dalam susunan organisasi BNN Kota ${ }^{57}$ yang mempunyai sejumlah tugas, di antaranya melakukan peningkatan kemampuan lembaga rehabilitasi medis dan rehabilitasi sosial penyalah guna dan/atau pecandu narkotika baik yang diselenggarakan pemerintah maupun masyarakat, peningkatan kemampuan layanan pasca rehabilitasi dan pendampingan, penyatuan kembali ke dalam masyarakat, dan evaluasi dan pelaporan di bidang rehabilitasi dalam wilayah Kabupaten/Kota. ${ }^{58}$

Peraturan Kepala BNN Nomor 4 Tahun 2015 Tentang Tata Cara Peningkatan Kemampuan Lembaga Rehabilitasi Medis dan Rehabilitasi Sosial yang Diselenggarakan oleh Pemerintah/ Pemerintah Daerah maupun Masyarakat semakin mempertegas bahwa untuk di tingkat kota, peningkatan kemampuan lembaga rehabilitasi yang diselenggarakan baik oleh pemerintah/pemerintah daerah maupun masyarakat dilaksanakan oleh Seksi Rehabilitasi BNN Kota. ${ }^{59}$

Sebagai suatu lembaga yang bersifat vertikal, dalam pelaksanaan kewenangan melakukan rehabilitasi tersebut, BNN Kota mendapat pembinaan teknis dan supervisi P4GN di bidang rehabilitasi dari BNN Provinsi. Adapun struktur yang melakukan pembinaan teknis dan supervisi terhadap BNN Kota dalam hal ini adalah Bidang Rehabilitasi, ${ }^{60}$ yang secara lebih spesifik dilaksanakan oleh Seksi Penguatan Lembaga Rehabilitasi dan Seksi Pascarehabilitasi BNN Provinsi. ${ }^{61}$

\footnotetext{
${ }^{57}$ Pasal 25 huruf (d) Peraturan Kepala BNN Nomor 3 Tahun 2015 Tentang Organisasi dan Tata Kerja BNN Provinsi dan BNN Kabupaten/Kota.

${ }^{58}$ Lihat Pasal 28 Peraturan Kepala BNN Nomor 3 Tahun 2015 Tentang Organisasi dan Tata Kerja BNN Provinsi dan BNN Kabupaten/Kota.

${ }^{59}$ Lihat Pasal 14 ayat (1) dan (2) Peraturan Kepala BNN Nomor 4 Tahun 2015 Tentang Tata Cara Peningkatan Kemampuan Lembaga Rehabilitasi Medis dan Rehabilitasi Sosial yang Diselenggarakan Oleh Pemerintah/Pemerintah Daerah Maupun Masyarakat.

${ }^{60}$ Pasal 15 huruf f Peraturan Kepala BNN Nomor 3 Tahun 2015 Tentang Organisasi dan Tata Kerja BNN Provinsi dan BNN Kabupaten/Kota.

${ }^{61}$ Asal 17 ayat (1) dan (2) Peraturan Kepala BNN Nomor 3 Tahun 2015 Tentang Organisasi dan Tata Kerja BNN Provinsi dan BNN Kabupaten/Kota.
} 


\section{KERTHA PATRIKA}

Volume 38, Nomor 1, Januari-April 2016

\section{Implementasi Aturan Mengenai Rehabilitasi terhadap Penyalah Guna Narkotika oleh Ba- dan Narkotika Nasional Kota Denpasar}

Hasil penelitian secara garis besar menunjukkan bahwa terbentuknya BNN Kota Denpasar mengakibatkan penanganan Narkotika lebih jelas dan terkoordinasi. Hal ini dibuktikan dengan lebih banyaknya terungkap dan lebih banyak barang bukti yang disita, dan yang lebih penting lagi lebih banyak generasi muda terselamatkan dari bahaya Narkotika.

Data yang tercatat di BNN Kota Denpasar menunjukkan bahwa hingga kuartal terakhir tahun 2015, terdapat 8.000 orang penyalahguna narkotika, dari 66 ribu orang total di seluruh Bali. ${ }^{62}$ Berdasarkan data yang didapatkan dari BNN, sejumlah pengguna narkotika di kota Denpasar dalam periode 2013-2015 tersebar di beberapa tempat untuk menjalankan rehabilitasi, seperti digambarkan dalam tabel di bawah ini.

\section{Tabel 1}

Lokasi Rehabilitasi Pengguna Narkotika dari Denpasar

\begin{tabular}{|c|c|c|c|c|}
\hline Tahun & Jumlah & Umur & $\begin{array}{c}\text { Jenis Yang } \\
\text { Disalahgunakan }\end{array}$ & Lokasi Rujukan \\
\hline \multirow[t]{3}{*}{2013} & \multirow[t]{3}{*}{3} & 38th & Methamphetamine & Balai Rehab Lido (Bogor) \\
\hline & & 40th & Methamphetamine & Balai Rehab Lido (Bogor) \\
\hline & & 41th & Amphetamine & Balai Rehab Lido (Bogor) \\
\hline \multirow{4}{*}{2014} & \multirow{4}{*}{4} & 32th & Methamphetamine & Balai Rehab Lido (Bogor) \\
\hline & & 18th & Amphetamine & Balai Rehab Baddoka (Makasar) \\
\hline & & 37 th & Putau & Balai Rehab Baddoka (Makasar) \\
\hline & & 39th & Marijuana & Balai Rehab Lido (Bogor) \\
\hline \multirow{7}{*}{2015} & \multirow{7}{*}{30} & 37 th & Amphetamine & Balai Rehab Lido (Bogor) \\
\hline & & 21th & Sabu-Sabu & Yayasan Gerasa \\
\hline & & 39th & Sabu-Sabu & Yayasan Dua Hati \\
\hline & & 38th & Sabu-Sabu & Yayasan Yakita \\
\hline & & 42th & Sabu-Sabu & Yayasan Yakeba \\
\hline & & 46th & Sabu-Sabu & Yayasan Yakita \\
\hline & & 33th & Sabu-Sabu & Yayasan Dua Hati \\
\hline
\end{tabular}

${ }^{62}$ Artikel, Kota Denpasar Bangun Pusat Rehabilitasi Narkoba, the President Post, September 2015, http://thepresidentpostindonesia.com/2015/09/07/kota-denpasar-bangun-pusat-rehabilitasi-narkoba/7

74 | Jurnal Ilmiah Fakultas Hukum Universitas Udayana 


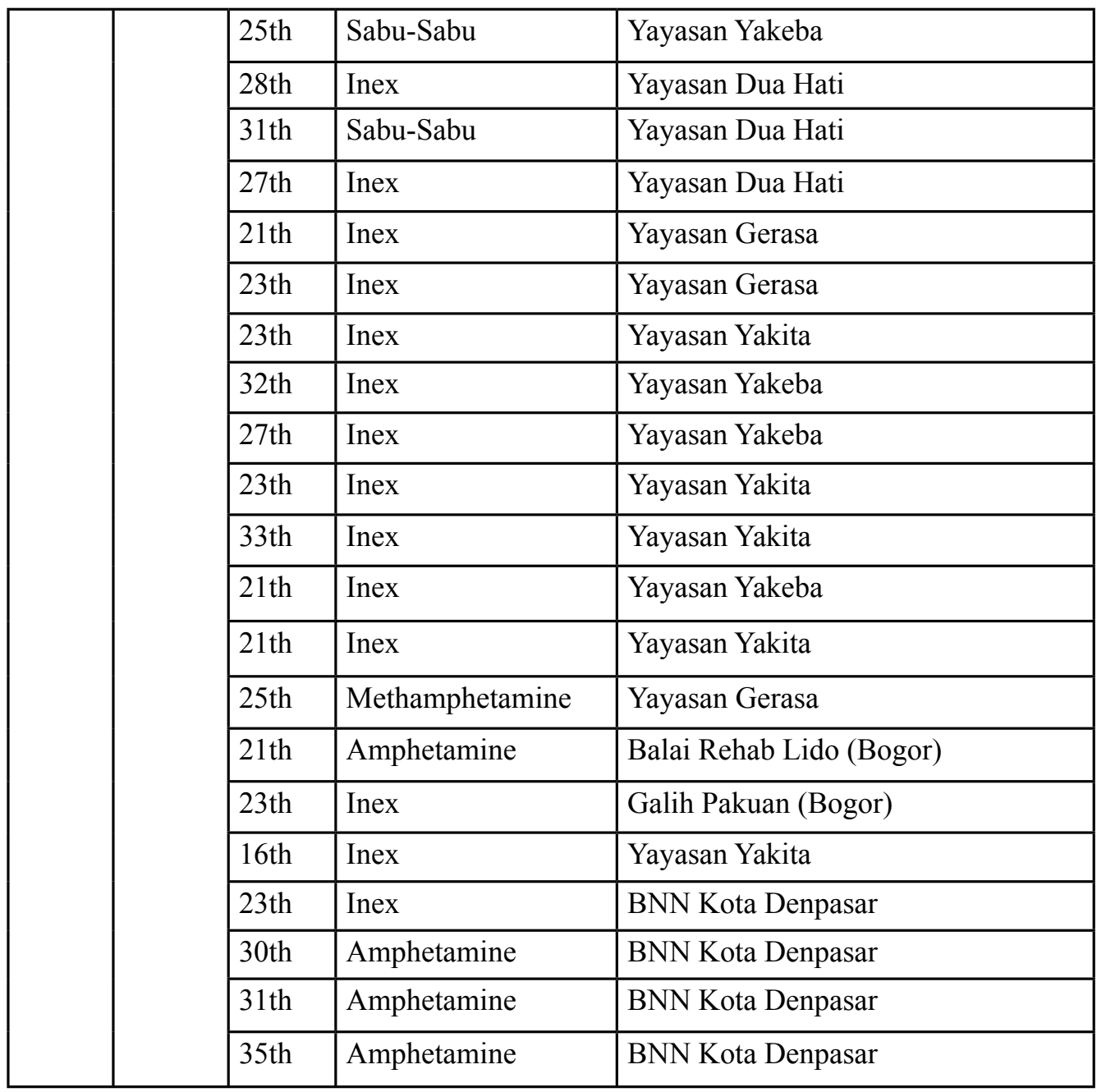

Sumber data: BNN Kota Denpasar

Data di atas menunjukkan bahwa pemberian rehabilitasi di tahun 2013 dan tahun 2014 tidak terlalu banyak, yaitu hanya terhadap 3 orang di tahun 2013 dan 4 orang di tahun 2014. Adapun lonjakan peningkatan yang sangat tinggi dalam pelaksanaan rehabilitasi terjadi di tahun 2015 yang mencapai 30 orang, sehingga lebih dari tujuh kali lipat dari yang dilakukan di tahun 2014.

Menariknya, penyalah guna narkotika yang diberikan program rehabilitasi di tahun 2015, sekitar separuhnya merupakan orang yang berusia kurang dari 30 tahun, yaitu sebanyak 15 orang. Hal ini mengindikasikan bahwa narkotika telah merambah kalangan remaja dan dewasa. Adapun orang yang berada pada masa kerja produktif di kisaran 30-39 tahun yang mengikuti program rehabilitasi adalah sebanyak 10 orang atau sekitar sepertiga dari total orang yang mengikuti rehabilitasi di tahun 2014.

Kebutuhan panti rehabilitasi tampak sangat mendesak sehingga perlu pemikiran untuk membuat panti rehabilitasi mengingat selama ini para pecandu Narkotika dititipkan di pantipanti rehabilitasi yang berada di luar daerah, ataupun terkadang dititipkan di rumah sakit yang 


\section{KERTHA PATRIKA}

Volume 38, Nomor 1, Januari-April 2016

ada di kota Denpasar. Padahal dilihat dari data pengguna narkotika di Denpasar, rumah sakit akan sangat kewalahan dalam menampung para korban penyalah guna narkotika.

Menurut Kepala BNN Kota Denpasar AKBP I Wayan Gede Suwahyu, ${ }^{63}$ Provinsi Bali, khususnya Denpasar, belum memiliki panti rehabilitasi bagi pecandu. Untuk itulah diperlukan sebuah tempat bagi mereka yang menjalani pemulihan, apalagi saat ini fungsi dokter khusus yang menangani hal tersebut belum berperan secara maksimal. Berkaitan dengan hal ini, BNN Kota Denpasar menganggap perlu segera dibangun tempat pemulihan bagi pecandu, sehingga upaya kuratif dan rehabilitatif tersebut dapat terlaksana sesuai apa yang diamanatkan oleh undang-undang. Hal ini diharapkan dapat membantu korban atau pengguna untuk keluar dari ketergantungan dan dapat hidup produktif di tengah-tengah masyarakat. Cara tepat untuk penanganannya adalah rehabilitasi, sehingga tidak menimbulkan pengguna-pengguna baru lagi.

Kepala BNN Kota Denpasar juga menyatakan bahwa BNN Kota Denpasar telah melakukan berbagai langkah mulai dari sosialisasi, rehabilitasi sampai pada tindakan. ${ }^{64}$ Sosialisasi yang dilakukan menyasar berbagai instansi sampai pada sekolah untuk menekan meningkatnya pengguna narkoba di kalangan generasi muda. Bahkan sekarang ada program baru untuk mengurangi pengguna narkoba dengan melakukan rehabilitasi. ${ }^{65}$ Untuk tempat rehabilitasi pihaknya telah mempersiapkan tempatnya di Kantor BNN Kota Denpasar, yang berlokasi di Jalan Melati Denpasar.

Secara teknis, Standar Operasional Prosedur (SOP) alur pelayanan penindakan yang dilakukan oleh BNN Kota Denpasar, dapat diuraikan sebagai berikut:

a. Program Detoksifikasi dan Stabilisasi, lamanya 1 (satu) bulan.

Pada fase ini, pecandu menghadapi gejala putus zat (withdrawal). Untuk membantu melewati masa putus zat digunakan pendekatan pharmakoterapi dengan cara simptomatik atau substitusi.

b. Program Primer, lamanya 6 (enam) bulan.

Fase dilakukannya perubahan-perubahan yang bersifat internal. Pada fase ini dibangun kembali sikap, pola hidup, kemampuan mengelola emosi, pemahaman dan penerimaan diri, dan intelektual. Fase ini merupakan landasan bagi proses pertumbuhan seorang pecandu dalam menjalankan pemulihannya.

c. Program Re-Entry, lamanya 6 (enam) bulan.

Maksud dari re-entry adalah kembali berintegerasi dengan kehidupan sosial masyarakat (mainstream). Pada fase ini seorang pecandu di dalam program sudah mulai kembali berintegerasi dengan lingkungan sosial masyarakat.

Kepala BNN Kota Denpasar juga menghimbau masyarakat yang memiliki keluarga sebagai

\footnotetext{
${ }^{63}$ Wawancara yang dilakukan penulis kepada AKBP I Wayan Gede Suwahyu, BNN Kota Denpasar, tanggal 1 September 2015.

${ }^{64}$ Ibid.

${ }^{65}$ Ibid.
}

76 | Jurnal Ilmiah Fakultas Hukum Universitas Udayana 
pengguna untuk melaporkan kepada BNN Kota Denpasar. Tentunya tidak ada proses hukum melainkan akan segera direhabilitasi secara gratis. Langkah tersebut merupakan salah satu kebijakan pusat agar masyarakat sebagai pecandu tidak perlu dipidanakan melainkan direhabilitasi, hanya pengedar yang harus mendapatkan sanksi berat sehingga peredaran narkoba dapat ditekan.

Saat ini BNN Kota Denpasar diharuskan oleh BNN Pusat untuk mencari dan merehabilitasi 600 pengguna narkotika di Kota Denpasar. Dari 600 pengguna yang disasar pihaknya baru mendapatkan 100 pengguna dan masih kurang dari target untuk direhabilitasi. ${ }^{66}$ Ia menduga, masyarakat masih banyak yang takut untuk melaporkan diri sebagai pengguna.

Untuk tahun 2015, BNN Kota Denpasar menganggarkan dana sebesar Rp 5,5 juta per orang untuk biaya transportasi rehabilitasi pecandu narkoba. Sebagaimana dikemukakan Kepala Seksi Pemberdayaan BNN Kota Denpasar Agung Putra Wijaya, S.H, BNN Kota Denpasar mengalokasikan lima orang untuk direhabilitasi di Bogor dan Makasar dengan alokasi transportasi 27,5 juta. Adapun biaya rehabilitasi ditanggung pemerintah pusat. ${ }^{67}$

\section{Kesimpulan Dan Saran}

\section{Kesimpulan}

Ada dua hal yang dapat disimpulkan dari penelitian ini, yaitu:

a. Badan Narkotika Nasional Kota (BNNK) memiliki kewenangan dalam penerapan rehabilitasi bagi penyalahgunaan Narkotika sebagaimana diatur di dalam Peraturan Presiden Republik Indonesia Nomor 23 Tahun 2010 tentang Badan Narkotika Nasional, Peraturan Kepala BNN Nomor 3 Tahun 2015 Tentang Organisasi dan Tata Kerja BNN Provinsi dan BNN Kabupaten/Kota, dan Peraturan Kepala BNN Nomor 4 Tahun 2015 Tentang Tata Cara Peningkatan Kemampuan Lembaga Rehabilitasi Medis dan Rehabilitasi Sosial yang Diselenggarakan oleh Pemerintah/Pemerintah Daerah maupun Masyarakat. Secara teknis, pelaksanaan terhadap kewenangan tersebut dilaksanakan oleh Seksi Rehabilitasi BNNK. Sebagai suatu lembaga yang bersifat vertikal, dalam pelaksanaan kewenangan untuk melakukan rehabilitasi tersebut, BNNK mendapat pembinaan teknis dan supervisi P4GN di bidang rehabilitasi dari BNN Provinsi. Adapun struktur yang melakukan pembinaan teknis dan supervisi terhadap BNNK dalam hal ini adalah Bidang Rehabilitasi, yang secara lebih spesifik dilaksanakan oleh Seksi Penguatan Lembaga Rehabilitasi dan Seksi Pasca rehabilitasi BNN Provinsi.

b. Secara garis besarnya, BNN Kota Denpasar telah mengimplementasikan aturan mengenai rehabilitasi terhadap penyalah guna narkotika. Hal ini dapat dilihat dari pelaksanaan sosialisasi rehabilitasi gratis bagi pengguna narkotika, penyediaan tempat rehabilitasi di Kantor

\footnotetext{
${ }^{66}$ Ibid.

${ }^{67}$ Artikel, Rehabilitasi Pecandu Narkoba, BNN Denpasar Anggarkan Rp 5,5 Juta Per Orang, Bali Post, 6 Februari 2015, http://balipost.com/read/sosial/2015/02/06/29443/rehabilitasi-pecandu-narkoba-bnn-denpasar-anggarkan-rp-55-juta-per-orang. html
} 


\section{KERTHA PATRIKA}

Volume 38, Nomor 1, Januari-April 2016

BNN Kota Denpasar yang berlokasi di Jalan Melati Denpasar, dan pemberian fasilitas transportasi bagi orang yang mengikuti program rehabilitasi di luar Bali. Selain itu, BNN Kota Denpasar juga telah memiliki SOP alur pelayanan penindakan yang dilakukan yang mencakup Program Detoksifikasi dan Stabilisasi, Program Primer, dan Program Re-Entry.

\section{Saran}

Ada dua saran yang hendak dikemukakan sebagai refleksi dari penelitian ini, yaitu:

a. Proses penegakan hukum sesungguhnya tidak dapat mengabaikan budaya hukum masyarakat setempat. Mempertimbangkan efektivitas lembaga adat dan peran prajuru adat di Bali, khususnya Denpasar, BNN Kota Denpasar perlu menyusun program rehabilitasi yang terinkorporasi dengan Banjar/Desa Pakraman di Denpasar.

b. Sebagai implementasi atas Pasal 57 Undang-Undang Nomor 35 Tentang Narkotika BNN Kota Denpasar perlu menginisiasi peran majelis keagamaan dan organisasi-organisasi keagamaan di tingkat Kota Denpasar untuk menyusun dan melaksanakan program-program riil penyembuhan pecandu yang diselenggarakan oleh masyarakat melalui pendekatan keagamaan.

\section{DAFTAR PUSTAKA}

\section{A. Buku}

Asmarawati, Tina, 2015. Pidana dan Pemidanaan dalam Sistem Hukum di Indonesia (Hukum Penitensier), Deepublish,Yogyakarta.

Krisnawati, Dani, Eddy O.S. Hiariej. 2006.Bunga Rampai Hukum Pidana Khusus, Pena Pundi Aksara, Jakarta.

Syamsudin, Aziz. 2011. Tindak Pidana Khusus, Sinar Grafika, Jakarta.

Weda Darma, Made, 1999. Kronik dalam Penegakan Hukum Pidana, Guna Widya, Jakarta.

Widjaya A. W.1985. Masalah kenakalan Remaja dan Penyalahgunaan Narkotika, Armico, Bandung.

\section{B. Penelitian dan Karya Ilmiah}

Krisnawati, Dani dan Niken Subekti Budi Utami.“Pelaksanaan Rehabilitasi Bagi Pecandu Narkotika Pada Tahap Penyidikan Pasca Berlakunya Peraturan Bersama 7 (Tujuh) Lembaga Negara Republik Indonesia", Laporan Penelitian Unit Penelitian dan Pengabdian Kepada Masyarakat Fakultas Hukum Universitas Gadjah Mada (PPM-FH UGM), Yogyakarta.

78 | Jurnal Ilmiah Fakultas Hukum Universitas Udayana 
Chandra, Heldy.Analisis Peranan Badan Narkotika Nasional Provinsi Dalam Pencegahan dan Penanggulangan Peredaran Narkotika Di Provinsi Sulawesi Selatan, Tesis Program Studi Kesehatan Masyarakat, Program Pasca Sarjana Universitas Hasanuddin, Makassar.

\section{Jurnal}

Musdalifah, "Peran Balai Rehabilitasi Badan Narkotika Nasional (BNN) Tanah Merah Dalam Merehabilitasi Pecandu Narkoba Di Kota Samarinda”, eJournal Ilmu Pemerintahan, 2015, 3 (2) : 718 730, Ilmu Pemerintahan, Fakultas Ilmu Sosial dan Ilmu Politik, Universitas Mulawarman.

Mcleod, Allegra M., "Decarceration Courts: Possibilities and Perils of a Shifting Criminal Law", The Georgetown Law Journal, 2012, Vol. 100.

Nalle, Victor Immanuel W.“The Relevance of Socio Legal-Studies in Legal Science”, Mimbar Hukum, 2015, Vol. 27, Nomor 1.

\section{Internet}

“Presiden SBY Luncurkan Gerakan Indonesia Bebas Narkoba 2015”.http://www.antaranews.com/, 26 Juni 2011.

“Operasi Pemetaan Kasus Narkotika di Daerah Kota Denpasar”. http://bali.bnn.go.id/, 18 Juni 214.

"BNN dan SKPD Kota Denpasar Ikut Selamatkan Generasi Muda". https://bnnkdenpasar.wordpress.com/,1 April 2014.

"BNNK Denpasar Mengajak Bendesa Pakraman Memerangi Narkoba". https://bnnkdenpasar. wordpress.com/, 11 Februari 2014.

"Penghuni Kost Ini Kaget BNN Denpasar Tes Urin Saat Dini Hari. http://bali.tribunnews.com/, 27 Juni 2015.

"BNNK Denpasar Adakan Sosialisasi P4GN untuk Siswa SMPN 1". https://bnnkdenpasar.wordpress.com/, 25 April 2014.

"BNNK Denpasar Mensosialisasi P4GN Pada Siswa SMPN 9 \& 11 Denpasar". https://bnnkdenpasar.wordpress.com/, 20 Februari 2014.

"Membangun Paradigma Dekriminalisasi Korban Pengguna Narkoba". http://www.gepenta.com/, 8 November 2012.

"Diguga Suka Menikmati Sisha, 50 siswa SMPN 5 Denpasar Dites Urin oleh BPN". http://suluhbali.co/, 20 September 2014.

"BNN Kota Denpasar Menguji Urine Siswa SMKN 4 Denpasar", Badan Narkotika Nasional Kota Denpasar". https://bnnkdenpasar.wordpress.com/, 9 Mei 2015. 


\section{KERTHA PATRIKA}

Volume 38, Nomor 1, Januari-April 2016

"Siswa SMK Kertha Wisata Dites Urine". http://pendidikan.denpasarkota.go.id/,18 Agustus 2014.

"Perangi Narkoba, Siswa SMAN 5 Denpasar Dites Urine Badan Narkotika Nasional Denpasar". https://bnnkdenpasar.wordpress.com/, diakses 21 April 2014.

“BNN Tes Urine Siswa, Dua Positif”. http://balipost.com/, 24 Maret 2014.

"BNNK Denpasar Mengetes Urine Pegawai Dispenda". https://bnnkdenpasar.wordpress.com/, 10 Maret 2014.

“55Karyawan Toko Swalayan Tiara Dewata Nasional Kota Denpasar”. https://bnnkdenpasar.wordpress.com/, 5 Maret 2014

"Dites BBNK Denpasar Karyawan Swhowroom Mobil Sempat Panik". https://bnnkdenpasar. wordpress.com/, 8 April 2014.

"BNNK Denpasar Advokasi Pegawai BPAD". https://bnnkdenpasar.wordpress.com/, 11 Maret 2014.

“Anggota Kodim 1611 Badung mendapatkan Advokasi P4GN". https://bnnkdenpasar.wordpress. com/, 3 Maret 2014.

"BNNK Denpasar Memberikan Advokasi P4GN pada siswa Ashram Paramadharma". https://bnnkdenpasar.wordpress.com/, 24 Februari 2014.

"Kota Denpasar Bangun Pusat Rehabilitasi Narkoba". http://thepresidentpostindonesia.com/, 7 September 2015.

"Rehabilitasi Pecandu Narkoba, BNN Denpasar Anggarkan Rp 5,5 Juta Per Orang”. http://balipost.com/, 6 Februari 2015.

"Punishment Fails, Rehabilitation Works". Http://Www.Nytimes.Com/, 19 Desember 2012

“ASEAN Sepakat Perlu Paradigma Baru Penanganan Narkoba”. http://103.3.70.3/portal/_uploads/ post/2015/07/06/Majalah_Sinar_Edisi_XI_2014.pdf, 6 Juli 2015

"Ketua DPR: Pengguna Narkotika Lebih Baik Direhabilitasi Daripada Dipenjara".http://foblog. psikomedia.com/, 26 Januari 2014.

\section{E. Peraturan Perundang-undangan dan Dokumen}

Undang-Undang Nomor 35 Tahun 2009 Tentang Narkotika (Lembaran Negara Republik Indonesia Tahun 2009, Nomor 143, Tambahan Lembaran Negara Republik Indonesia Tahun Nomor 5062)

Peraturan Pemerintah Nomor 25 Tahun 2011 Tentang Pelaksanaan Wajib Lapor Pecandu Narkotika (Lembaran Negara Repubik Indonesia Tahun 2011, Nomor 46, Tambahan Lembaran Negara Republik Indonesia Nomor 5211)

Peraturan Pemerintah Nomor 40 Tahun 2013 Tentang Pelaksanaan Undang-Undang Nomor 35

80 Jurnal Ilmiah Fakultas Hukum Universitas Udayana 
Tahun 2009 Tentang Narkotika (Lembaran Negara Repubik Indonesia Tahun 2013 Nomor 96, Tambahan Lembaran Negara Republik Indonesia Nomor 5419)

Peraturan Presiden Nomor 23 Tahun 2010 Tentang Badan Narkotika Nasional

Instruksi Presiden Nomor 12 Tahun 2011 tentang Pelaksanaan Kebijakan dan Strategi Nasional Pencegahan dan Pemberantasan Penyalahgunaan dan Peredaran Gelap Narkoba Tahun 2011-2015

Peraturan Menteri Kesehatan Nomor 50 Tahun 2015 Tentang Petunjuk Teknis Pelaksanaan Wajib Lapor dan Rehabilitasi Medis Bagi Pecandu, Penyalahguna, dan Korban Penyalahgunaan Narkotika, Berita Negara Republik Indonesia Tahun 2015 Nomor 1146.

Peraturan Bersama Ketua Mahkamah Agung, Menteri Hukum dan Hak Asasi Manusia, Menteri Kesehatan, Menteri Sosial, Jaksa Agung Republik Indonesia, Kepala Kepolisian, Kepala Badan Narkotika Nasional Tentang Penanganan Pecandu Narkotika dan Korban Penyalahgunaan Narkotika ke dalam Lembaga Rehabilitasi Nomor : PERBER/01/III/2014/BNN

Peraturan Daerah Provinsi Bali Nomor 3 tahun 2001 tentang Desa Pakraman, Lembaran Daerah Provinsi Bali Tahun 2003 Nomor 11, Tambahan Lembaran Daerah Provinsi Bali Nomor 3.

Kementerian Luar Negeri, Daftar Perjanjian Internasional (Tersimpan di Kementerian Luar Negeri, Republik Indonesia)

Surat Edaran Mahkamah Agung Nomor 3 Tahun 2011 tentang Penempatan Korban Penyalahgunaan Narkotika di dalam Lembaga Rehabilitasi Medis dan Rehabilitasi Sosial

Peraturan Kepala Badan Narkotika Nasional Nomor 11 Tahun 2014 Tentang Tata Cara Penanganan Tersangka dan/atau Terdakwa Pecandu Narkotika dan Korban Penyalahgunaan Narkotika ke dalam Lembaga Rehabilitasi (Berita Negara Republik Indonesia Tahun 2014 Nomor 844)

Peraturan Kepala Badan Narkotika Nasional Nomor 3 Tahun 2015 Tentang Organisasi dan Tata Kerja BNN Provinsi dan BNN Kabupaten/Kota (Berita Negara Republik Indonesia Tahun 2015 No. 493)

Peraturan Kepala BNN Nomor 4 Tahun 2015 Tentang Tata Cara Peningkatan Kemampuan Lembaga Rehabilitasi Medis dan Rehabilitasi Sosial yang Diselenggarakan oleh Pemerintah/ Pemerintah Daerah Maupun Masyarakat (Berita Negara Republik Indonesia Tahun 2015 Nomor 770)

Keputusan Kepala Badan Narkotika Nomor: KEP/422/XII/KA OT.01/ 2015 /BNN Tentang Road Map Reformasi Birokrasi Badan Narkotika Nasional Tahun 2015 -2019 